\title{
Pelatihan Mendeley Pada Mahasiswa Universitas Teuku Umar
}

\author{
Triyanto1, Rahma Husna Yana $^{2}$, Nurkhalis ${ }^{3}$ \\ 1,2,3Jurusan Sosiologi, Universitas Teuku Umar \\ Email: triyanto@utu.ac.id \\ Email: husnayana@utu.ac.id \\ Email: Nurkhalis@utu.ac.id
}

Submitted: 08-05-2020 Revised: 25-06-2020 Accepted: 27-06-2020

\begin{abstract}
Every college wants to always advance and look the best in the mind of the general public or the world of education. Being the best and the advanced campus can now be seen from several indicators, including the work of lecturers and students recognized by academics who produce many writings as their work and works that can be adopted or used by the community in meeting their needs. The recognition of academics can be seen by the citation from the work of lecturers and students earlier. But not all the work of lecturers and students can be cited due to incorrect writing techniques. The intended writing technique is the use of applications in conducting quotes, specifically quoting the scientific work of lecturers and students who first produced scientific work. The problem is that there are not many students even lecturers currently mastering the application. For this reason, this activity is carried out so that students can write good scientific papers using the Mendeley application. The activity was attended by highly educated people around Meulaboh City. After this activity, the highly educated people who followed were able to carry out scientific writing with quotation techniques using the Mendeley application.
\end{abstract}

Keywords: Thesis, Article, Reference, Quote, Mendeley

\begin{abstract}
Abstrak
Setiap perguruan tinggi ingin selalu maju dan tampak terbaik di mata masyarakat umum atau pun dunia pendidikan. Menjadi terbaik dan kampus maju itu saat ini dapat dilihat dari beberapa indikator, diantaranya adalah karya dosen dan mahsiswa diakui oleh akademisi yang banyak menghasilkan tulisan sebagai hasil karyanya maupun karya yang dapat diadopsi atau digunakan masyarakat dalam memenuhi kebutuhan hidupnya. Adapun pengakuan akademisi itu dapat dilihat dengan adanya sitasi dari karya dosen dan mahasiswa tadi. Namun tidak semua karya dosen dan mahasiswa dapat disitasi dikarenakan teknik penulisan yang salah. Teknik penulisan yang dimaksud adalah penggunaan aplikasi dalam melakukan kutipan, khususnya mengutip karya ilmiah dosen dan mahasiswa yang lebih dahulu menghasilkan karya ilmiah. Yang menjadi masalah adalah tidak banyak mahasiswa bahkan dosen saat ini yang menguasai aplikasi tersebut. Untuk itu kegiatan yang dilakukan agar mahasiswa mampu melakukan penulisan karya ilmiah yang baik menggunkan aplikasi mendeley. Kegiatan diikuti mahasiswa yang berada di sekitar Kota Meulaboh. Setelah dilakukan kegiatan ini masyarakat berpendidikan tinggi yang mengikuti mampu melakukan penulisan ilmiah dengan teknik kutipan yang menggunakan aplikasi mendeley.
\end{abstract}

Kata Kunci: Kutipan, Mendeley, Aplikasi, Karya Ilmiah, Sitasi

\section{PENDAHULUAN}

Setiap perguruan tinggi

memiliki target untuk selalu maju

dan tampak terbaik di mata masyarakat umum atau pun dunia pendidikan. Menjadi kampus terbaik dan maju dapat dilihat melalui beberapa indikator, 
diantaranya adalah karya dosen dan mahasiswa yang diakui oleh akademisi dan banyak menghasilkan tulisan sebagai hasil karyanya maupun karya yang dapat diadopsi atau digunakan masyarakat dalam memenuhi kebutuhan hidupnya.

Namun, karya ilmiah tersebut juga harus yang berkualitas. Salah satu indikasi kualitas karya ilmiah adalah berkaitan dengan tidak terkena unsur plagiasi. Meskipun hal ini sering tidak disengaja oleh seorang penulis, dan plagiasi terjadi karena minimnya pengetahuan tentang teknik-teknik pengutipan atau cara melakukan sitasi (Hasanah et al., 2019).

Adapun yang dimaksud dengan karya ilmiah dalam hal ini sesuai dengan pendapat Tanjung, yakni hasil pengembangan pemikiran dan penerapan teknologi yang diperoleh melalui proses penelitian. Karya ilmiah harus mengikuti kaidahkaidah penulisan yang baik (Rahmawati et al., 2018). Tuntutan karya ilmiah untuk sitasi ini bukan hanya kepada dosen saja tetapi juga karya ilmiah mahasiswa. Beberapa perguruan tinggi menerapkan publikasi karya ilmiah mahasiswa tingkat sarjana sebagai syarat pengambilan mata kuliah. Sementara itu standar nasional pendidikan tinggi menyebutkan bahwa penilaian akreditasi mempertimbangkan jumlah karya ilmiah milik mahasiswa pascasarjana yang telah dipublikasikan serta tersitasi (BANPT, 2019). Sedangkan pada mahasiswa strata 1 (sarjana) masih sebatas terpublikasi untuk mendapatkan penilaian akreditasi.

Adapun pengakuan akademisi itu dapat dilihat dengan adanya sitasi dari karya dosen dan mahasiswa tadi. Namun tidak semua karya dosen dan mahasiswa dapat disitasi, hal ini bisa dikarenakan teknik penulisan yang salah. Teknik penulisan yang dimaksud adalah penggunaan aplikasi dalam melakukan kutipan, khususnya mengutip karya ilmiah dosen dan mahasiswa yang lebih dahulu menghasilkan karya ilmiah.

Sejumlah aplikasi yang dapat digunakan mahasiswa maupun dosen untuk melakukan penulisan kutipan dalam karya-karya ilmiahnya. Aplikasi microsoft word sekarang ini juga sudah menyediakan tool untuk melakukan kutipan. Tool tersebut diletakkan pada tab references yang diberi judul ribbon citation $\mathcal{E}$ bibliography. Aplikasi lainnya yang bisa digunakan dan mudah ditemukan adalah End, zootero, dan mendeley (Pramiastuti, Rejeki and Pratiwi, 2020). Masing-masing aplikasi tentu memiliki kelebihan dan kekurangan mamsing-masing tergantung 
bagaimana

pengguna

memanfaatkan aplikasi-aplikasi ini.

Berbagai kelebihan dalam penggunaan aplikasi sitasi ini cukup banyak, diantaranya adalah penulis mampu menampilkan sumber referensi pada tulisannya dengan kaidah penulisan yang benar, penulis juga menjamin pembacanya bisa mengakses sumber primer tulisan dengan mudah melalui fasilitas yang disediakan aplikasi sitasi, yaitu penulisan sumber rujukan atau daftar bibliografi (Nurisani et al., 2019).

Aplikasi yang akan digunakan dalam pelatihan ini adalah aplikasi mendeley, yaitu sebuah aplikasi yang dikembangkan oleh "Gregor Mendel" dan "Dmitri Mendeleyev" dimana aplikasi ini diluncurkan oleh Mendeley Ltd untuk memudahkan penulis dalam mengelola referensi / literatur (Supianti, 2018). Meskipun banyak juga aplikasi yang lain, namun mendeley lebih populer setidaknya di kalangan dosen dan mahasiswa lingkup Universitas Teuku Umar.

Dengan pelatihan ini diharapkan peserta yang mengikuti kegiatan ini dapat menyumbangkan karya ilmiahnya serta menyumbangkan jumlah sitasi yang banyak bagi prodi khususnya dan universitas pada umumya. Dengan banyaknya sitasi yang dimiliki akan menambah angka pada saat akreditasi sehingga meningkatkan grade kampus. Jelas bahwa pelatihan mendeley ini akan meningkatkan kemampuan menulis bagi dosen dan sangat penting dalam meningkatkan kualitas pendidikan (Pahmi et al., 2018).

\section{METODE PELAKSANAAN}

Dua langkah yang ditempuh dalam melakukan pelatihan ini, yaitu tahap persiapan dan tahap pelaksanaan. Tahap persiapan meliputi pemberian informasi dan identifikasi peserta peminat pelatihan. Sedangkan tahap pelaksanaan meliputi pembagian aplikasi mendeley, cara install aplikasi, dan teknik penggunaan aplikasi mendeley. Adapun penjelasan secara detail mengenai tahapan tersebut yaitu, 1) Memberikan informasi kepada mahasiswa bahwa akan dilakukan kegiatan sosialisasi penggunaan aplikasi. Informasi ini diberikan pada WAG yang pesertanya bisa terdiri dari mahasiswa dari berbagai tempat yang tertarik, 2) Melakukan identifikasi mahasiswa yang tertarik untuk mengikuti pelatihan penggunaan mendeley. Membagikan aplikasi mendeley yang digunakan dalam pelatihan kepada peserta, 4) Memberikan pelatihan cara install / memasang aplikasi ke dalam laptop, dan 4) 
Memberikan pelatihan cara menggunakan aplikasi mendeley.

\section{HASIL DAN PEMBAHASAN} Tahap Pemberian Informasi dan identifikasi

Kegiatan tahap pertama terkait dengan memberikan informasi kepada mahasiswa yang dilakukan menggunakan aplikasi Whatsapp group, khususnya pada grup mahasiswa sosiologi pada tingkat akhir. Kelompok mahasiswa pada tingkat akhir ini memiliki banyak grup seperti mata kuliah, unit, prodi, dan tugas akhir. Hal ini sudah dipertimbangkan, dimana hampir semua mahasiswa menggunakan media sosial WhatsApp, sedangkan aplikasi lainnya belum tentu memiliki. Kalau pun memiliki diperkirakan tidak banyak dan jarang diakses. Media sosial yang sering diakses dan digunakan berkomunikasi sehari-hari adalah WhatsApp, apalagi hampir semua mahasiswa juga menjadi anggota dalam grup baik yang dibuat oleh program studi, dosen, atau mahasiswa khususnya grup mata kuliah tertentu. Artinya informasi melalui media sosial whatsapp lebih mudah dan lebih cepat menyebar.

Berdasarkan respon anggota grup, dapat diketahui mayoritas mahasiswa yang sedang menyusun tugas akhir berupa skripsi sangat tertarik untuk mengikuti kegiatan pelatihan ini. Namun banyaknya peminat yang akan mengikuti pelatihan ini kemudian menimbulkan permasalahan tersendiri, yaitu keterbatasan tempat untuk melakukan kegiatan.

Oleh karena itu, peserta diberikan persyaratan harus membawa laptop dalam pelatihan dimaksud. Hal ini juga sangat masuk di akal, karena tanpa membawa peralatan seperti laptop pelatihan hanya akan menjadi forum atau kegiatan sosialisasi saja. Setelah dilakukan persyaratan tersebut maka didapatkan peserta yang benar-benar bisa melakukan pelatihan dengan membawa laptop sendiri. Peserta yang dapat mengikuti adalah: Nurma Sari, TR. Bukhari, M. Yasir, Ulvika Ramayanti, Baihaki, Nira Wati, Suriani, Luski Rudilah, Rika Sandeva, Fitri Wahyuni, Wista Yulanda, Rubami, Rosmawati, Yudia Anisa, Melia Safitri, Wirda Rahmi, Cut Evi devina angelina, Irma Oktavia, Nova Mauliza, dan Rauzah Munawir.

Adanya kepastian jumlah calon peserta, sangat memungkinkan untuk dilakukan tahapan berikutnya yaitu tahap pelatihan.

Sebagai akhir dari tahap persiapan penting untuk mempersiapkan aplikasi mendeley yang telah di unduh (download) 
secara gratis. Berikutnya bagi peserta yang menginginkan aplikasi yang berbayar bisa dilakukan sendiri melalui website mendeley (www.mendeley.com).

\section{Tahap Pelaksanaan Pelatihan}

Setelah peserta mendapatkan aplikasi yang dibagikan melalui flashdisk, berikutnya adalah melakukan pemasangan aplikasi mendeley pada laptop. Kendala ditemukan pada saat pemasangan aplikasi, yang menyebabkan tidak semua peserta berhasil melakukan install aplikasi. Pemeriksaan dilakukan melalui kronologi pemasangan. Akhirnya dapat ditemukan penyebab terjadinya kegagalan pada beberapa laptop peserta, ternyata operating system (OS) yang digunakan oleh masingmasing laptop sebagai perangkat

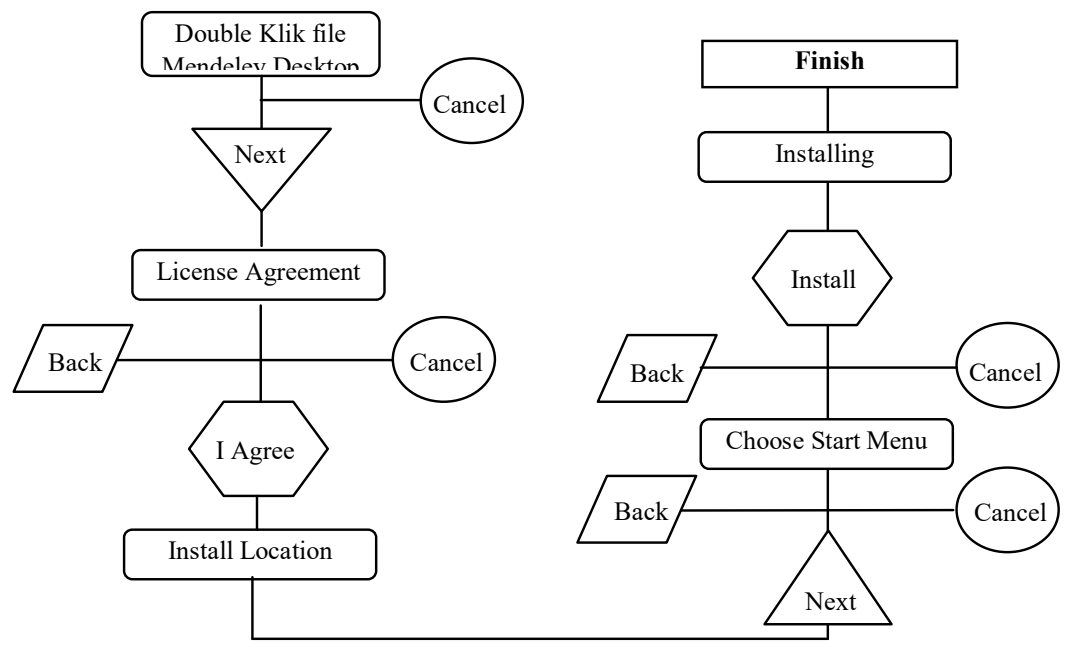

Gambar 1: Diagram alur install aplikasi memiliki ketidaksamaan, yakni sebagian dengan operating system 32bit dan sebagian lagi 64-bit.

Sementara itu aplikasi yang sudah dibagikan hanya untuk laptop dengan operating system 64bit. Penggunaan aplikasi yang sesuai dengan operating system yang tertanam pada laptop adalah solusi yang harus dilakukan. Untuk itu, perlu dicarikan aplikasi dengan spesifikasi yang sesuai dengan 32bit operating system. Setelah diperoleh aplikasi dengan spesifikasi ini kemudian dibagikan kepada mahasiswa yang menggunakan laptop dengan spesifikasi tersebut.

Sesi berikutnya memandu peserta untuk melakukan proses install (pemasangan) aplikasi. Alur pemasangan aplikasi dapat dilihat dalam gambar berikut: 
Secara teknis instalasi yang sudah dilakukan dengan cara-cara sebagai berikut:

1. Klik dua kali pada nama file yang telah diberikan secara gratis sebagaimana dimaksud di atas.
2. Setelah proses pertama dilakukan akan muncul Kotak dialog welcome to the Mendeley Desktop Setup Wizard, ada opsi next dan cancel. Pilih dan Tekan "next"

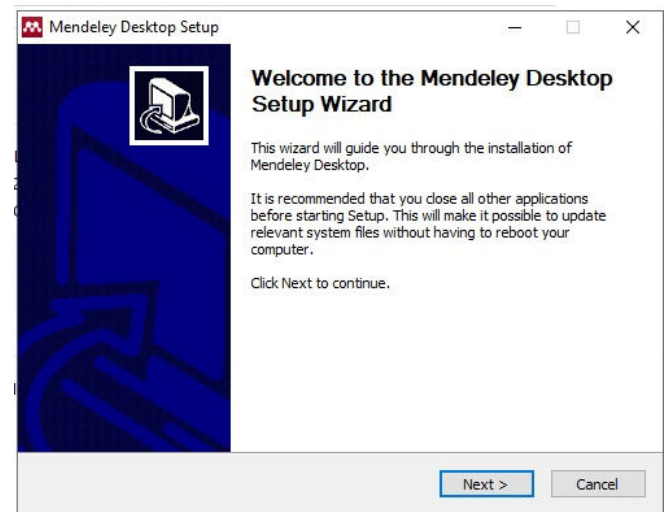

Gambar 2: Kotak dialog panduan pertama install

3. Setelah opsi "next" dipilih, maka berikutnya akan keluar kotak dialog mendeley desktop setup. sepakat harus pilih "I Agree". Jika memilih "cancel" aplikasi tidak akan terpasang.

4. Pada kotak dialog ini berisi tentang licence agreement. Jika

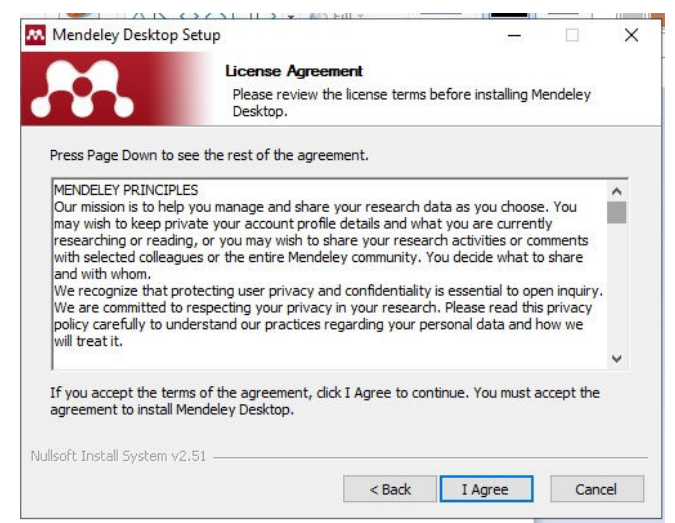

Gambar 3: Kotak dialog license agreement

5. Setelah klik "I Agree", maka akan keluar kotak dialog yang mempertanyakan tentang dimana aplikasi mendeley ini akan dipasang. Aplikasi mendeley ini secara default 


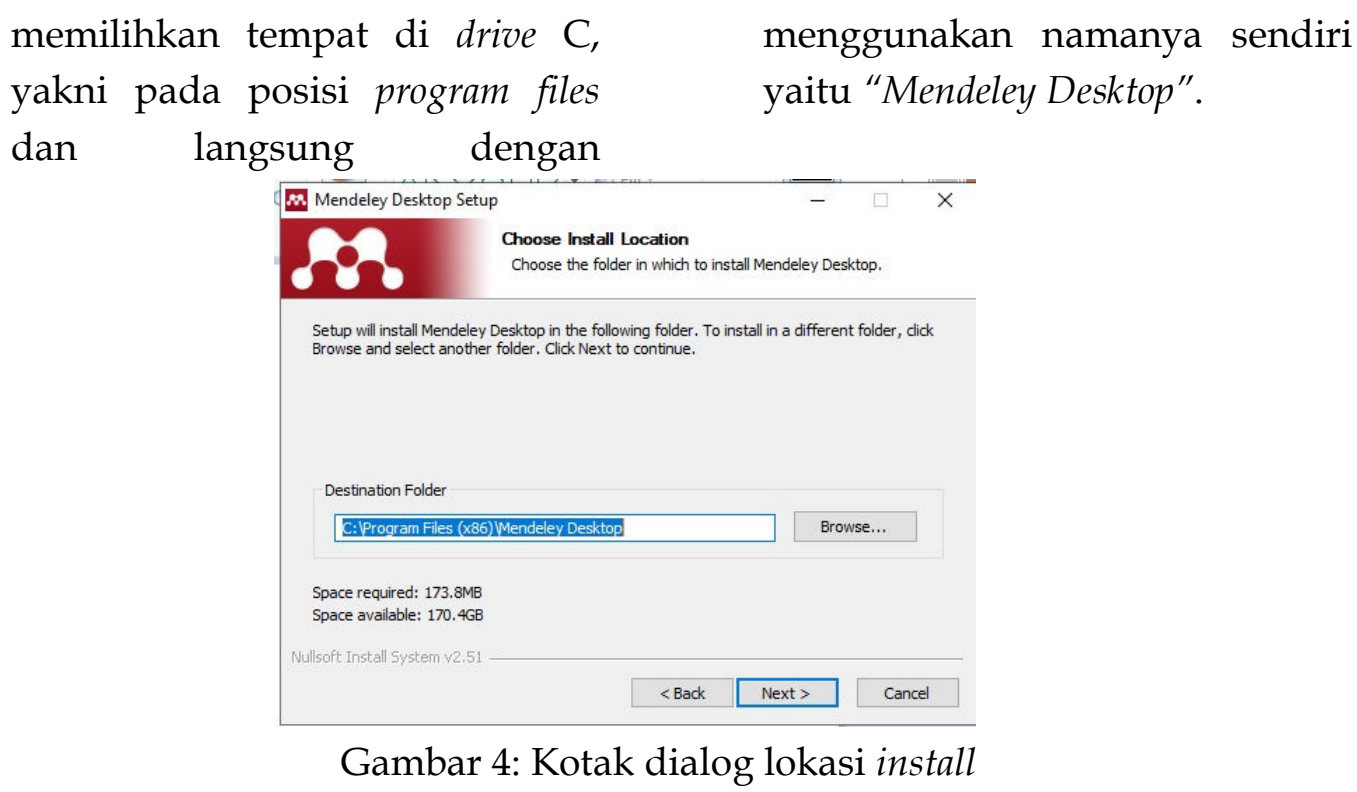

6. Setelah klik "next", maka kembali keluar kotak dialog yang mempertanyakan mengenai menu shortcut. Tidak perlu lamalama karena ini bisa diabaikan saja. Tetapi kalau mengganti agar sesuai dengan keinginan dan mempermudah ingatan pemilik laptop. Bahkan memilih untuk tidak membuat shortcut juga diberikan opsinya. Pilih nama shortcut juga bisa lakukan

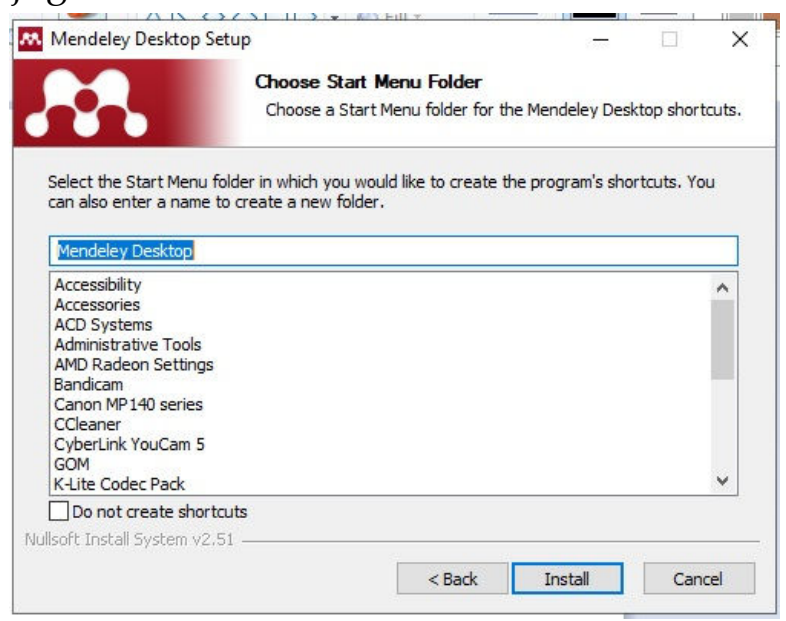

Gambar 5: Pilihan folder start menu

7. Selanjutnya akan keluar kotak dialog bahwa pemasangan aplikasi sedang dalam proses.
Dalam hal ini bisa dipantau sejauhmana persentase sudah dicapai. Proses ini tidak akan 
lama karena aplikasi ini memang bukan aplikasi yang sangat besar, aplikasi ini sangat kecil dan ringan sehingga tidak

Mendeley Desktop Setup

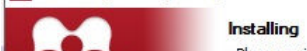

Please wait while Mendeley Desktop is being installed.

Extract: locales-pt-BR.xml

Show details

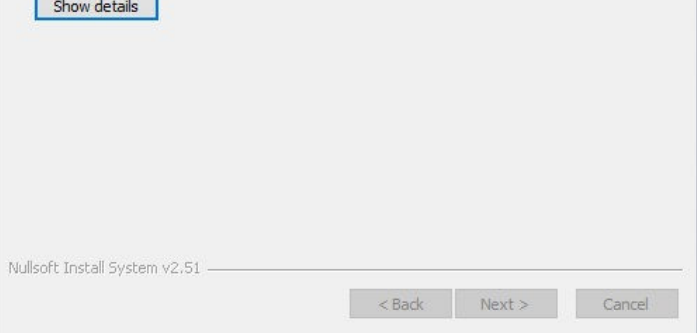

Gambar 6: Proses dan kemajuan install memerlukan waktu yang lama dalam melakukan pemasangan atau instalasi.
8. Proses instalasi selesai, kemudian keluar kotak dialog yang menyatakan bahwa proses intalasi sudah selesai. Untuk menyelesaikan instalasi harus klik tab "Finish". Namun sebelumnya ada pertanyaan apakah begitu klik "finish"

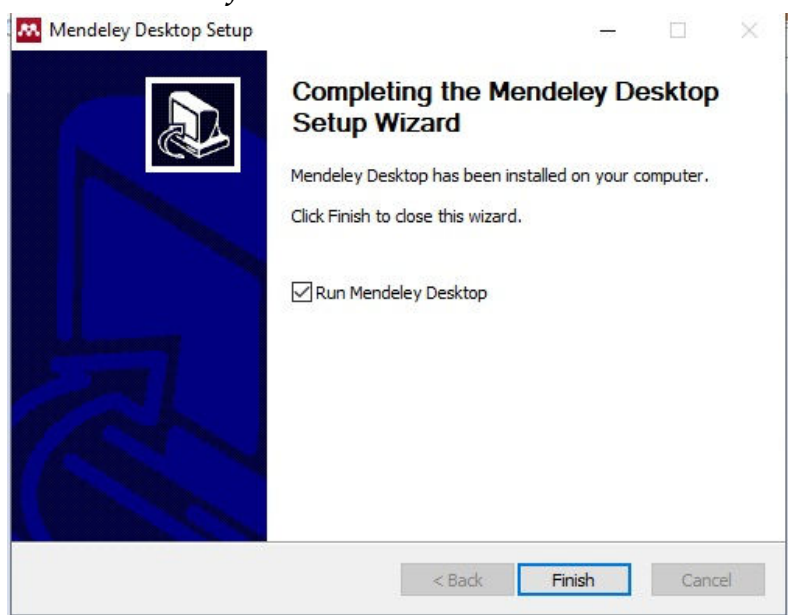

Gambar 7: Proses install selesai aplikasi langsung terbuka atau tidak. Jika menginginkan Klik finish kemudian langsung membuka aplikasi mendeley ini, maka perlu di contreng kotak yang di sisi kanannya ada tulisan "Run Mendeley Desktop".
9. Langkah berikutnya harus
klik "Finish" oleh karena sudah melakukan register, jadi setelah memilih atau men-contreng 
"Run Mendeley Desktop" maka aplikasi langsung terbuka. Akan tetapi sebelum terbuka sepenuhnya diwajibkan pengguna melakukan registrasi, maka keluar pertama kali adalah kotak dialog register. Dalam hal ini kita harus mengisi email dan password.

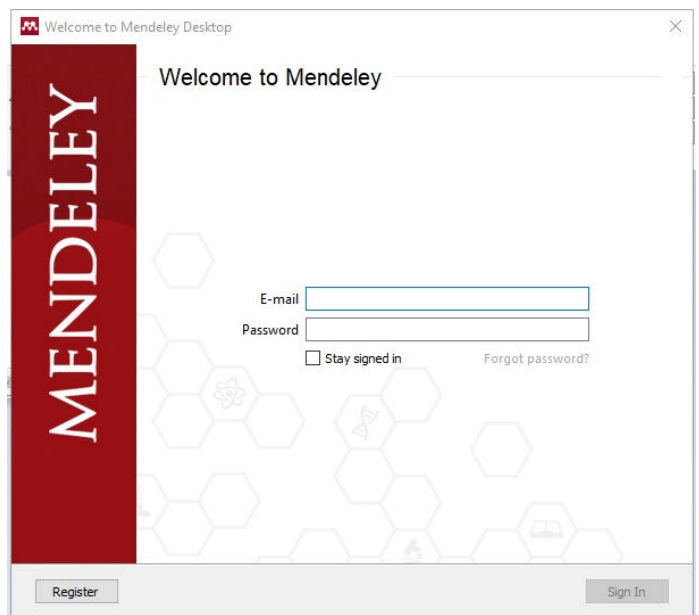

Gambar 8: Kotak dilaog register dan login

10. Setelah isi email dan password, klik pada register. Jika proses sudah bisa digunakan, seperti registrasi selesai maka aplikasi

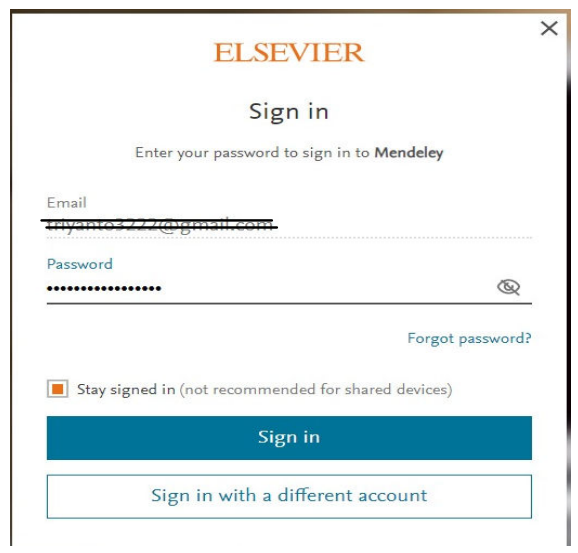

Gambar 9: Kotak dialog sign in setelah register

11. Pada penggunaan pertama akan diberikan pilihan untuk pemasangan secara integrasi pada aplikasi microsoft word.
Pemilihan untuk menekan tombol install now untuk citation plugin akan mengintegrasikan mendeley ke 
dalam sistem sitasi yang sudah ada dan merupakan bawaan aplikasi microsoft word. Sementara itu pemilihan import document or library pada reference manager akan mendownload semua file-file yang diperlukan ke dalam aplikasi mendeley yang telah terpasang pada laptop atau komputer dimana prosesnya telah dilewati di atas, seperti tampilan berikut:

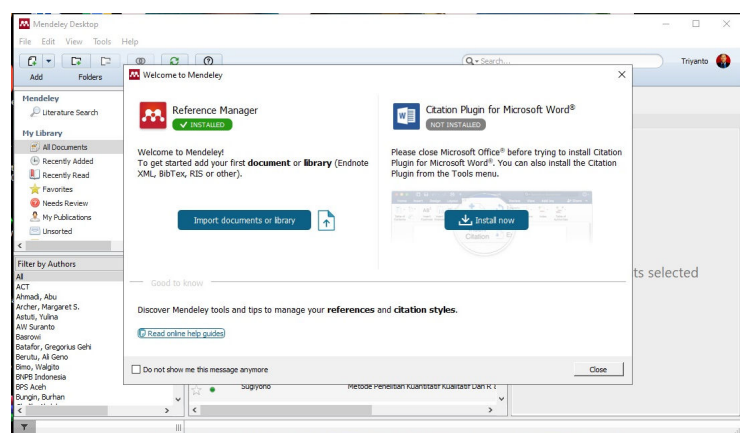

Gambar 10: Pilihan untuk install mendeley pada MS word

\begin{abstract}
Selama
proses install, disediakan wifi gratis untuk membantu peserta dalam melakukan registrasi. Aplikasi mendeley ini memerlukan koneksi internet selama registrasi, jika koneksi internet kurang memadai maka registrasi akan mengalami kegagalan. Kegagalan akan berakibat pada tidak berfungsinya aplikasi, bukan hanya gagal tetapi aplikasi memang tidak akan bisa dibuka.
\end{abstract}

\section{Proses Pelatihan Penggunaan Mendeley}

Sebelum menggunakan aplikasi mendeley, peserta diberikan pengetahuan mengenai teknikteknik kutipan baik yang dilakukan secara langsung maupun tidak langsung. Teknik ini sering digunakan para dosen dan mahasiswa di perguruan tinggi serta penulis-penulis karya ilmiah lainnya. Pengetahuan ini sangat penting, mengingat aplikasi ini juga akan merujuk nama pemilik artikel / buku / referensi manapun yang karyanya akan dirujuk atau disitasi ke dalam karya ilmiah penulis. Berdasarkan pengalaman, sering terjadi kekeliruan yang dilakukan mahasiswa dalam menulis suatu kutipan. Kemunculan nama seorang penulis yang dikutip sebanyak dua kali dalam satu kalimat kutipan membuat kalimat tersebut tidak nyaman dilihat dan dibaca.

Teknik kutipan ini juga disesuaikan dengan ketentuan yang berlaku di Universitas Teuku Umar. Dalam ketentuan yang dimaksudkan itu tertuang aturan 
dimana kutipan langsung sejumlah 40 kata ke atas akan diperlakukan berbeda dengan yang kurang dari 40 kata. Hal ini memunculkan konsekuensi penulisan yang berbeda, namun dimanapun kutipan langsung selalu diberikan tanda petik di awal dan di akhir kalimat.

Paling penting diperhatikan adalah cara mengutip dari penulis yang juga mengutip atau kutipan di dalam kutipan. Banyak penulis dari kalangan mahasiswa yang mengutip pada artikel seseorang namun kemudian mengatasnamakan penulis yang dikutip pemilik naskah dengan memasukkan namanya yang tertera dalam daftar pustaka. Padahal, sering terjadi pemilik naskah sudah merubah redaksional sehingga tidak sama persis dengan kalimat yang dikutipnya. Jika kemudian kalimat baru ini dikutip dan mengatasnamakan nama penulis yang dikutip pemilik naskah, maka hal ini merupakan kesalahan besar.

Bagi mahasiswa selain menguasai penggunaan mendeley sangat penting juga untuk memperhatikan teknik kutipan yang berlaku di kampusnya masing-masing. Beberapa kampus memiliki panduan yang mengatur tentang teknik kutipan, ada yang membedakan antara kutipan langsung yang kurang dari 5 (lima) baris dengan yang lebih dari 5 (lima) baris (Subandar et al., 2015).

Alur pelaksanaan kegiatan secara rinci dapat dilihat dalam diagram berikut ini:

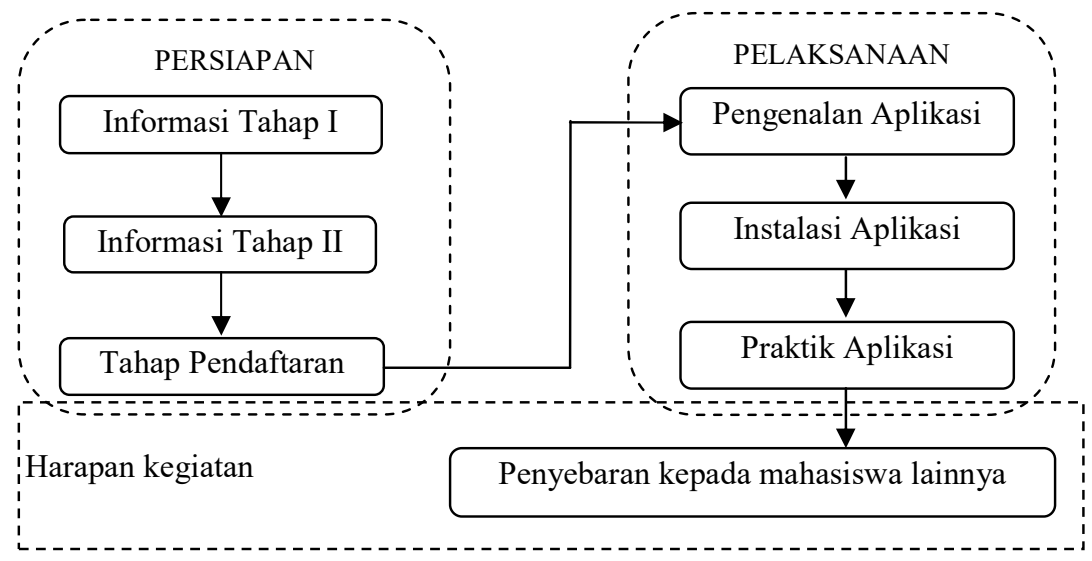

Gambar 11: Alur pelaksanaan kegiatan

\section{Peserta Pelatihan:}


Peserta yang benar-benar mengikuti pelatihan sejumlah 20 (dua puluh), aktivitasnya sebagaimana dalam gambar berikut:

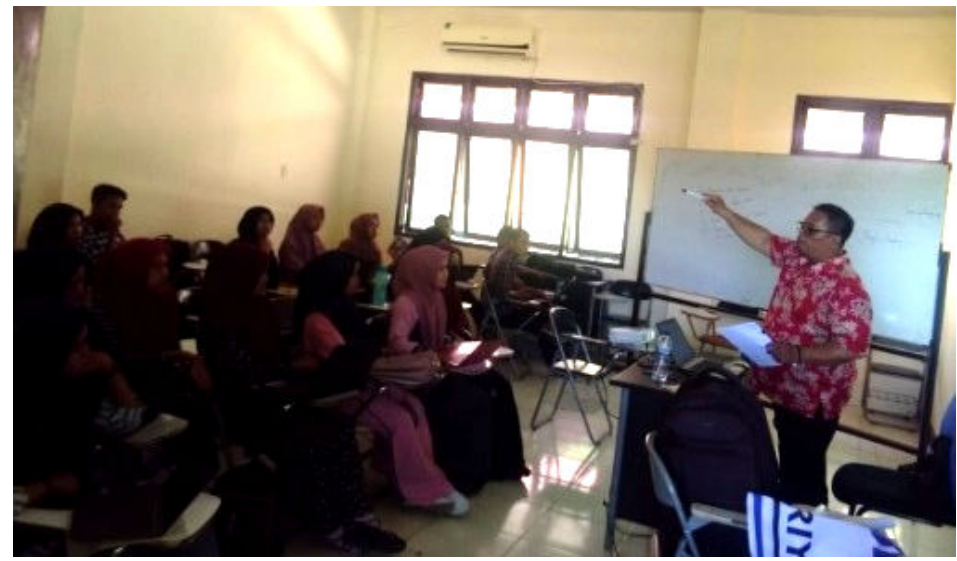

Gambar 12. Proses pelatihan / workshop

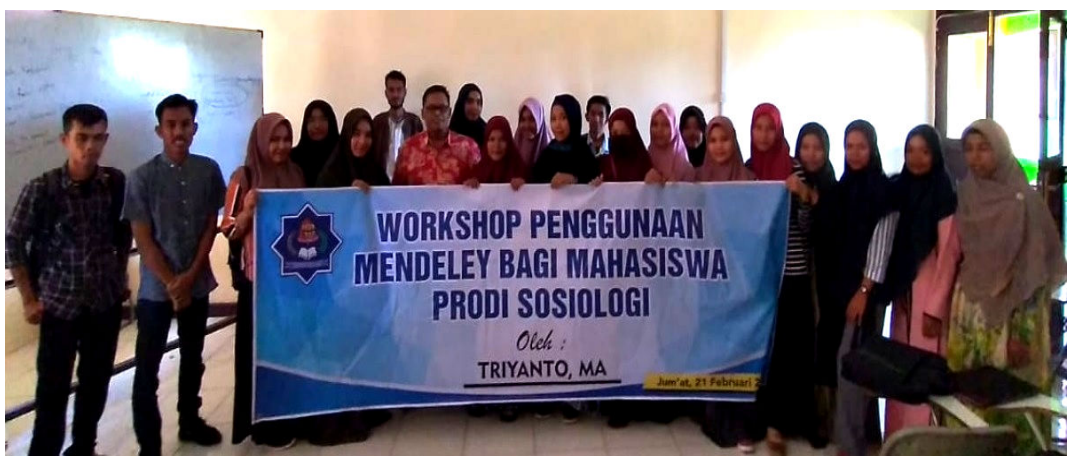

Gambar 13. Peserta pelatihan bersama pemateri

Setelah pemberian wawasan atau pengetahuan mengenai teknik kutipan yang disesuaikan dengan ketentuan yang berlaku di Universitas Teuku Umar yang merupakan kampus para peserta ini, peserta kemudian diberikan pelatihan cara-cara menggunakan aplikasi mendeley. Teknik pengutipan diberikan agar mampu melakukan kutipan dengan baik sehingga terhindar dari plagiasi.
Hasil penelitian menunjukkan bahwa plagiasi pada mahasiswa terjadi karena ketidaksengajaan saja tetapi juga karena ketidaktahuan prosedur pengutipan (Touwely et al., 2019).

Proses memasukkan bahan yang akan dijadikan referensi, atau file yang akan dikutip isi tulisannya merupakan hal pertama kali yang juga harus dipahami peserta. Proses ini bisa dilakukan secara manual 
dan bisa juga secara otomatis. Otomatis yang dimaksud di sini adalah memasukkan hanya dengan upload file yang sudah dimiliki oleh penulis. Bukan hanya satu file saja, tetapi upload atau unggah file bisa dilakukan dengan banyak file yang tergabung dalam sebuah folder. Proses entry file reference ini jauh lebih mudah jika penulis sudah memiliki dokumen atau file dan tergabung dalam sebuah folder (Djamaris, 2017). Dengan terkumpulnya bahan referensi pada satu folder ini penulis tinggal upload dan semua form yang semestinya diisi secara manual akan terisi secara otomatis. Akan tetapi jika proses entry form secara manual, akan cukup melelahkan karena ada banyak form yang harus diisi. Hal ini juga akan berbeda formulir isian ketika bahan rujukan atau referensi juga berbeda-beda. Maksudnya form isian untuk rujukan yang berupa buka, jurnal, prosiding, laporan penelitian, skripsi / tesis / disertasi dan bentuk-bentuk lainnya memiliki form yang berbeda-beda.

Proses pelatihan menemukan fakta bahwa peserta merasa kesulitan karena aplikasi ini menggunakan bahasa Inggris, sehingga kurang bisa dipahami apa yang harus diisi oleh peserta. Sebuah contoh istilah author, title, type, DOI, dan lain-lainnya, bagi beberapa peserta istilah-istilah ini belum bisa dipahami. Untuk itu, diperlukan penjelasan tambahan mengenai beberapa form yang harus diisi ketika melakukan entry file secara manual.

Bukan hanya istilah dalam form saja, tetapi termasuk juga apa yang dimaksud dengan journal article, conference proceeding, book, book section, dan lain-lainnya. Untuk itu, bagian ini juga penting untuk dijelaskan terlebih dahulu untuk membedakan antara yang dimaksud book dengan book section. Setelah peserta bisa membedakan dua hal itu, dilanjutkan dengan pemahaman mengenai journal article dan conference proceeding. Demikian seterusnya sampai peserta memahami jenis-jenis referensi yang harus dituliskan dalam database mendeley.

Setelah peserta memahami cara melakukan entry data referensi, tahapan berikutnya adalah mencari rujukan dan menempatkannya pada artikel yang sedang ditulis. Proses ini dalam pelaksanaannya jauh lebih mudah dan sangat sederhana. Semua peserta dapat mengikuti lebih cepat dari proses sebelumnya. Proses ini hanya menuliskan kalimat yang dikutip kemudian mencari nama penulis yang sudah dimasukkan dalam database mendeley. Pencarian hanya menekan icon insert citation pada aplikasi yang sudah terintegrasi 
dengan microssof word. Setelah itu akan keluar kotak dialog, dalam kotak dialog ketikkan nama yang dicari maka secara otomatis akan muncul daftar nama yang sudah diketikkan tadi. Selanjutnya tinggal memilih nama dan judul artikel yang dimaksudkan.

Hanya dengan demikian saja maka sitasi dari sumber rujukan telah terselesaikan. Bagian terakhir adalah memasukkan sumber rujukan yang disitasi ke dalam daftar pustaka. Bagian terakhir ini juga bukan merupakan hal yang sulit. Langkah yang diperlukan cukup sederhana yaitu menempatkan kursor pada area yang akan dituliskan daftar pustaka. Selanjutnya klik insert bibliography, dan tidak lama akan muncul semua sumber rujukan yang disitasi mengisi daftar pustaka. Berikutnya hanya mengatur layout daftar pustaka sesuai ketentuan yang berlaku.

\section{PENUTUP}

Setelah dilakukan pelatihan, dapat disimpulkan bahwa peserta sudah memiliki kemampuan diantaranya adalah:

1. Melakukan install mendeley ke dalam laptop/komputer sebagai alat penulisan sitasi/rujukan.

2. Melakukan entry data file reference dengan menggunakan aplikasi mendeley.
3. Menggunakan mendeley sebagai alat penulisan daftar pustaka atau bibliography.

5. DAFTAR PUSTAKA

BAN-PT (2019) 'Lampiran-2PerBAN-PT-No-2-Th'. Jakarta: BAN-PT, p. 27.

Djamaris, A. R. A. (2017) 'PanduanPenggunaan

Mendeley (Versi 1.17.10)', p. 32. Available at: http:/ / repository.bakrie.ac.id/ 1227/1/panduan mendeley.pdf.

Hasanah, M. et al. (2019) Laporan Kegiatan Pengabdian Kepada Masyarakat Pelatihan Penggunaan Aplikasi Zootero Untuk Pembuatan Sitasi dan Daftar Pustaka Pada Mahasiswa Pendidikan IPS FKIP Universitas Lambung Mangkurat. Banjarmasin. doi: 10.1145/2505515.2507827.

Nurisani et al. (2019) 'Perilaku Penggunaan Aplikasi Sitasi Mahasiswa (Studi Kasus di Program Studi Pascasarjana Fikom Unpad 2018)', PUSTABIBLIA: Journal of Library and Information Science, 3(1). doi: DOI: http:/ / dx.doi.org/10.18326/p ustabiblia.v3i1.75-88.

Pahmi, P. et al. (2018) 'Pelatihan Penggunaan Mendeley Untuk Referensi Dalam Menulis Karya Ilmiah Bagi Guru Sma Handayani Pekanbaru', Jurnal 
Pengabdian UntukMu NegeRI, 2(2), pp. 35-39. doi: 10.37859/jpumri.v2i2.849.

Pramiastuti, O., Rejeki, D. S. and Pratiwi, A. (2020) 'Pengenalan Dan Pelatihan Sitasi Karya Ilmiah Menggunakan Aplikasi Mendeley', Jurnal Abdimas Bhakti Indonesia, 1(1), pp. 24$30 . \quad$ doi: https:// doi.org/10.36308/abp. v1i1.178.

Rahmawati, C. et al. (2018) 'Pelatihan Software Mendeley Dalam Peningkatan Kualitas Artikel Ilmiah Bagi Dosen', Jurnal Pengabdian Kepada Masyarakat, 8(1), p. 30. doi: 10.30999/jpkm.v8i1.200.

Subandar, I. et al. (2015) Pedoman Skripsi. Meulaboh: Universitas Teuku Umar.

Supianti, I. I. (2018) 'Mendeley Sebagai Alat Bantu Dalam Penyusunan Referensi Artikel', Prosiding Seminar Nasional $\mathcal{E}$ Workshop, pp. 168-177.

Touwely, G. H. et al. (2019) 'Pendampingan Penulisan Karya Ilmiah Bagi Mahasiswa Desa Nusaniwe', Indonesian Journal of Cultural and Community Development, 4, pp. 23-31. Available at: https://journal.umsida.ac.id/i ndex.php/ijccd/article/view/ $70 / 165$. 